\title{
In vivo activity of two herbal plant mixtures against gastrointestinal nematodes in ruminants
}

\author{
Kimani, $\mathrm{D}^{1 *}$, Kareru, $\mathrm{P} \mathrm{G}^{1}$, Karanja, J M ${ }^{1}$, Njonge, $\mathrm{F} \mathrm{K}^{2}$, Githira $\mathrm{P} \mathrm{N}^{1}$, \\ Kutima, $\mathrm{HL}^{3}$, Mercy, $\mathrm{G}^{1}$ and Nyagah, $\mathrm{G} \mathrm{C}^{1}$ \\ ${ }^{1}$ Chemistry Department, College of Pure and Applied Sciences, Jomo Kenyatta University of Agriculture and \\ Technology, Kenya \\ ${ }^{2}$ Land Resource and Animal Sciences Department, Jomo Kenyatta University of Agriculture and \\ Technology, Kenya \\ ${ }^{3}$ Zoology Department, Jomo Kenyatta University of Agriculture and Technology, Kenya
}

\begin{abstract}
Helminthes infestation is a major constraint to livestock production. Increasing anthelmintic resistance and the impact of conventional anthelmintics on the environment has led to increased interest on new novel plant-based compounds. In this study, the in vivo activity of a herbal extract mixture containing Entada leptostachya and Prosopis juliflora was determined using faecal egg count (FEC) reduction tests on sheep. There were no signs of toxicity in all the groups throughout the study period apart from reduced feed intake in the initiation stage of the experiment. The herbal formula exhibited a time-dependent but not dose-dependent invivo anthelmintic activity. The $500 \mathrm{mg} / \mathrm{kg}$ b.w.dose produced the maximum faecal egg reduction of $84 \%$ while $4500 \mathrm{mg} / \mathrm{kg}$ b.w.dose gave the least reduction of $-59 \%$ on day 19 post-treatment (PT). The results of the FEC reduction tests indicated that the herbal formulation tested passed the threshold FEC reduction of $80 \%$. All the groups had an increase in their mean live body weights (LBWs) by day 19 PT except the untreated group. However, none of the increase was significant $(P>0.05)$. All the animals recorded pre-and post-treatment packed cell volume (PCV) values that were within the permissible range of between $24-45 \%$ for experimental sheep. All the groups recorded improved PCV values except the doses at $1500 \mathrm{mg} / \mathrm{kg} \mathrm{b.w.} \mathrm{and} 4500 \mathrm{mg} / \mathrm{kg} \mathrm{b.w.} \mathrm{In}$ conclusion, the herbal mixture was, therefore, safe and sufficiently active and has potential as a novel anthelmintic drug for the treatment of gastro-intestinal nematodes in ruminants.
\end{abstract}

Key words: Gastro-intestinal nematode, anthelmintic, faecal egg count, Prosopis juliflora

\section{Introduction}

Helminthiasis is one of the most common setbacks in production and reproductive performance of livestock (Agaie and Onyeyili, 2007; Dawo and Tibo, 2005). Most of the effects caused by helminth parasitoses go unnoticed because of sub-clinical or chronic nature of the diseases they cause unless the parasites cause death of the animal (Dawo and Tibo, 2005). Control of gastro-intestinal nematode (GIN) parasitism is usually based on the use of chemical anthelmintics, whose effectiveness and consistent use has been limited by high levels of anthelmintic resistance and high cost.

In this study, in vivo tests were conducted on sheep naturally infected with a mixture of gastrointestinal nematodes. In vivo tests using FEC involve feeding the ruminant animal with herbal extract followed by monitoring helminthes eggs in the animal feaces over time after administration. Reduction of feacal egg counts with time is an indication of in vivo anthelmintic activity (Githiori, 2004; Agaie and Onyeyili, 2007; Dawo and Tibbo, 2005; Krimpen et al., 2008; Burke et al., 2009; Deore and Khadabadi, 2010).

Entada leptostachya is found in several parts of Kenya (Machakos, Embu and Mbeere districts) and other parts of Africa such as Somalia, Ethiopia and Tanzania. The communities in Embu and Mbeere districts of Eastern Province, Kenya use the root bark decoction to treat worms in humans and animals (Kareru, 2008). Prosopis juliflora (locally known as 'Mathenge') was introduced in Kenya in the early 1970s (Ebenshade and Grainger, 1980, Maghembe et al., 1983) and is generally considered a noxious weed locally. This study, therefore, sought to determine the safety and in vivo activity using live animal model (sheep) of a formulated herbal extract mixture containing the two plants. This is in order to determine its safety and activity so as to confirm possible application as an anthelmintic for ruminants as a way of mitigating the negative attributes of $P$. Juliflora while providing a cheaper alternative for control of helminthes for small holder farmers and pastoralists. 


\section{Materials And Methods}

\subsection{Collection and preparation of medicinal plant material}

Entada leptostachya root barks were collected from Embu and Mbeere areas of Kenya. Prosopis juliflora leaves were collected from Marigat, Baringo County, Kenya. The plant specimen were identified in the field and authenticated by a plant taxonomist from the Botany Department at Jomo Kenyatta University of Technology (J.K.U.A.T.) where voucher specimens were also deposited. The samples were sorted, cleaned and air dried on the laboratory benches away from direct sunlight before being ground into fine powder and separately stored in air-tight plastic bags for further use to avoid contact with moisture.

Standard procedures (Lateef et al. (2003; 2006); Sujon et al., 2008; Krimpen et al., 2008) were used during the in vivo studies with a few modifications.

\subsection{Sourcing, housing and grouping of animals}

Sheep (male and female stock of 6-12 months) weighing between $13-26.5 \mathrm{~kg}$ were bought from Kariobangi livestock market in Nairobi, Kenya. They were transported to J.K.U.A.T. and left to graze and acclimatize for a month. The animals were housed in pre-designed animal shed in the university's animal farm consisting of five cubicles and a feed storage cubicle with each cubicle having a meshed window for ventilation and raised wooden floor, a wooden feeding trough and watering bucket. The animals were then grouped according to the various test concentrations of $500 \mathrm{mg} / \mathrm{kg}, 1,500 \mathrm{mg} / \mathrm{kg}$ and $4,500 \mathrm{mg} / \mathrm{kg}$ for the extract treatment groups, $10 \mathrm{mg} / \mathrm{kg}$ for the treated control group (Albendazole) and untreated control group. Each group consisted of two males and two females and the females were confirmed to be non-pregnant. The animals were randomly selected and assigned to the various groups so that the individual weights in each group were as close as possible. There was no physical contact between animals in different cubicles.

\subsection{Pre-treatment procedure}

The animals were left to acclimatize in the cubicles for about 2 days. The animals were fed on commercial feed supplemented with grass and they had ad libitum access to tap water. Feacal samples from each group were collected and egg count per gram (EPG) of their fresh feacal samples determined to confirm that the animals were naturally infected with mixed species of worms. The infected sheep were then regrouped again so that each group had low, medium and highly infected sheep. The sheep were then given unique individual identifications on laminated paper wound on their necks.

The fresh crude aqueous extract mixture and positive control (albendazole) were diluted in distilled water in graduated doses of $500 \mathrm{mg} / \mathrm{kg}, 1,500 \mathrm{mg} / \mathrm{kg}$ and $4,500 \mathrm{mg} / \mathrm{kg}$ for the aqueous extract mixture and $10 \mathrm{mg} / \mathrm{kg}$ for the positive control. The animals were fasted overnight with ad libitum access to water. On day 0 , the sheep were weighed using an overhead spring balance $(0-50 \mathrm{~kg}$ scale), fresh feacal samples collected directly via rectum into clean, capped, air-tight plastic sample containers ready for EPG counting. Fresh blood sampling was done directly from the sheep's ear capillary into heparinized microhaematocrit tubes ready for packed cell volume (PCV) determination (Hansen and Perry, 1994). The sheep were then treated with single doses of the crude extract mixture according to the animals' live body weights (LBWs) by varying the volume using the following equation:

$$
\text { Volume }(\mathrm{ml})=\frac{\text { Dose rate }\left(\mathrm{mg} / \mathrm{kg} b . w_{1}\right) \times \text { Body weight }(\mathrm{kg})}{\text { Concentration }(\mathrm{mg} / \mathrm{ml})}
$$

The sheep dosing was followed by further withdrawal of food for about 3 hours with ad libitum access to water and then fed with commercial feed supplemented with grass with ad libitum access to water. Fresh feacal samples were obtained from the sheep each morning via rectum on day 3, 7, 11, 15 and 19 post- treatment and screened for presence of nematode eggs by salt floatation technique and the EPG determined. The eggs were observed and counted using a modified McMaster egg counter with a sensitivity of 50 eggs per gram of feaces and feacal egg count percent reduction (FECR) calculated using the following formula:

$$
\% \text { FECR }=\frac{\text { Pr } e-\text { treatment egg count per gram }- \text { Post }- \text { treatment egg count per gram }}{\operatorname{Pr} e-\text { treatment egg count per gram }}
$$

Individual live body weights of the animals were taken on day 3, 7, 11, 15 and 19 using an overhead spring balance (0-50kg scale) and PCV also determined on day 0 and day 19. 


\subsection{Feacal egg count results}

\section{Results And Discussion}

Feacal egg counts (FEC) and their percentage reduction/increase are recorded in Table 1. These in vivo anthelmintic results for extract mixture are being reported for the first time by the time of conducting this study.

Table 1: Mean \pm S.D. $(n=4)$ EPG results after single oral administration of the herbal extract mixture to experimental sheep

\begin{tabular}{|c|c|c|c|c|c|}
\hline \multicolumn{2}{|c|}{ Day PT } & Controls & \multicolumn{3}{|c|}{ Herbal extract mixture dose (mg/kg b.w.) } \\
\hline & Untreated & $\begin{array}{l}\text { Albendazole } \\
(10 \mathrm{mg} / \mathrm{kg} \text { b.w. })\end{array}$ & 500 & 1500 & 4500 \\
\hline $\mathbf{0}$ & $\begin{array}{l}1325 \pm 1024.3 \\
(0 \%)\end{array}$ & $\begin{array}{l}1800 \pm 2079.7 \\
(0 \%)\end{array}$ & $\begin{array}{l}7963 \pm 6713.7 \\
(0 \%)\end{array}$ & $\begin{array}{l}6038 \pm 5861.9 \\
(0 \%)\end{array}$ & $\begin{array}{l}1513 \pm 904.9 \\
(0 \%)\end{array}$ \\
\hline 3 & $\begin{array}{l}12250 \pm 15033.4 \\
(-825 \%)\end{array}$ & $\begin{array}{l}3188 \pm 2131.7 \\
(-77 \%)\end{array}$ & $\begin{array}{l}18513 \pm 18896.7 \\
(-132 \%)\end{array}$ & $\begin{array}{l}8750 \pm 6559.1 \\
(-45 \%)\end{array}$ & $\begin{array}{l}6338 \pm 8877.3 \\
(-319 \%)\end{array}$ \\
\hline 7 & $\begin{array}{l}3050 \pm 2949.3 \\
(-130 \%)\end{array}$ & $\begin{array}{l}2225 \pm 1274.4 \\
(-24 \%)\end{array}$ & $\begin{array}{l}12263 \pm 8479.0 \\
(-54 \%)\end{array}$ & $\begin{array}{l}10537 \pm 7243.8 \\
(-75 \%)\end{array}$ & $\begin{array}{l}3825 \pm 1756.2 \\
(-153 \%)\end{array}$ \\
\hline 11 & $\begin{array}{l}6413 \pm 5906.3 \\
(-384 \%)\end{array}$ & $\begin{array}{l}2350 \pm 1931.3 \\
(-31 \%)\end{array}$ & $\begin{array}{l}6250 \pm 3946.1 \\
(22 \%)\end{array}$ & $\begin{array}{l}10587 \pm 10575.6 \\
(-75 \%)\end{array}$ & $\begin{array}{l}3750 \pm 1239.6 \\
(-148 \%)\end{array}$ \\
\hline 15 & $\begin{array}{l}1613 \pm 1438.4 \\
(-22 \%)\end{array}$ & $\begin{array}{l}883 \pm 800.5^{\mathrm{e}} \\
(51 \%)\end{array}$ & $\begin{array}{l}1775 \pm 885.5^{\mathrm{a}} \\
(78 \%)\end{array}$ & $\begin{array}{l}4938 \pm 4659.5^{\mathrm{b}} \\
(18 \%)\end{array}$ & $\begin{array}{l}2663 \pm 832.0^{\mathrm{c}} \\
(-76 \%)\end{array}$ \\
\hline 19 & $\begin{array}{l}7288 \pm 7530.1 \\
(-450 \%)\end{array}$ & $\begin{array}{l}1333 \pm 548.5 \\
(-26 \%)\end{array}$ & $\begin{array}{l}1313 \pm 438.5^{\mathrm{a}} \\
(84 \%)\end{array}$ & $\begin{array}{l}4863 \pm 3336.8^{\mathrm{b}} \\
(19 \%)\end{array}$ & $\begin{array}{l}2413 \pm 2148.8 \\
(-59 \%)\end{array}$ \\
\hline
\end{tabular}

PT=Post treatment; Untreated=Naturally infected but untreated control group; $\mathbf{b . w .} .=$ body weight; values with same lettered superscripts are significantly different $(\mathrm{P}<0.05)$ from day 0 FEC in the same column; Negative percentage values indicate the extent of increase in FEC value compared to day 0 PT

There were no signs of toxicity such as salivation, diarrhea and skin reaction in all the groups throughout the study period apart from reduced feed intake in the initiation stage of the experiment. The herbal extract mixture showed a time-dependent but not dose-dependent in vivo anthelmintic activity. Albendazole and the herbal extract mixture showed a general positive in vivo anthelmintic activity compared to untreated control. The high faecal egg counts could be attributed to the high presence of adult parasites in reproductive stages in the host (Worku et al., 2009). There was a general increase in FEC in all the animal groups on day 3, with a general drop from day 7 except for treatment group at $1500 \mathrm{mg} / \mathrm{kg}$ b.w. This increase in FEC could have been due to reduced faecal output hence, a virtually higher faecal nematode egg concentration (Githiori, 2008). This was caused by general reduction in the animals' feed intake by day 0 post treatment. This may be attributed to a shorter period of acclimatization to the commercial feed leading to poor palatability despite supplementing the commercial feed with grass. However, the feed intake had improved by day 5 post-treatment after mineral supplementation was introduced on day 4 post-treatment.

The peak anthelmintic effects of the herbal extract mixture doses show a decreasing anthelmintic activity with increasing dosage with a similar trend having been observed by Lateef et al. (2006) with crude methanolic extract of Carum copticum. The peak FEC reductions for Albendazole and extract mixtures at $500 \mathrm{mg} / \mathrm{kg}$ b.w. and $1500 \mathrm{mg} / \mathrm{kg}$ b.w. were significant $(\mathrm{P}<0.05)$. The $500 \mathrm{mg} / \mathrm{kg}$ b.w. group produced a maximum faecal egg count reduction (FECR) of $84 \%$ on day 19 post-treatment (PT) followed by $1500 \mathrm{mg} / \mathrm{kg}$ b.w. group which gave $19 \%$ on day 19 PT while $4500 \mathrm{mg} / \mathrm{kg}$ b.w. group gave the least reduction of $-59 \%$ on day 19 PT while Albendazole gave $51 \%$ on day 15 PT. This, however, should not be construed to mean that the $1500 \mathrm{mg} / \mathrm{kg}$ and $4500 \mathrm{mg} / \mathrm{kg}$ doses were ineffective as there was a consistent FEC reduction from day 7 post-treatment for both dose levels though the herbal drug at $4500 \mathrm{mg} / \mathrm{kg}$ b.w. was not able to reduce the FEC below the pretreatment EPG. Probably, drug metabolism/breakdown could have taken longer with increase in dosage. The 
other reason for this observation could have been due to early saturation of the aqueous solutions of the individual plants during preparation of the extracts. With a peak faecal egg reduction of $84 \%$, the $500 \mathrm{mg} / \mathrm{kg}$ b.w. dose passed the threshold FEC reduction.

Wood et al. (1995) reports that any anthelmintic product that reduces FEC by less than $80 \%$ during FECR test trial should be considered insufficiently active as a curative agent. Githiori (2008) considered FEC and total worm count (TWC) reductions greater than or equal to $70 \%$ biologically significant based on the same guideline. The $500 \mathrm{mg} / \mathrm{kg}$ b.w. dose may not have been affected by slow drug metabolism and this could provide direction on the maximum dose necessary to produce better in vivo anthelmintic effects.

The herbal extract mixture formula exhibited in vivo anthelmintic activity against mixed gastrointestinal nematodes. This could be attributed to the mixture of polar phytochemicals present in $E$. leptostachya and $P$. juliflora which are soluble in aqueous medium. Phytochemical studies done on the two plants confirm the presence of alkaloids, flavonoids, saponins, tannins and sterols/triterpenes from the leaf aqueous extracts of P. juliflora (Wamburu et al., 2013) while root aqueous extracts of E. leptostachya have tested positive for sterols/triterpenes, glycosides, saponins and tannins (Kareru, 2008; Kareru et al., 2012). Condensed tannins can impair vital processes such as feeding and reproduction of the parasite or may bind and disrupt the integrity of the parasite's cuticle (Dave et al., 2009; Zafar et al., 2009). It is reported that monodesmoside saponins have shown to destabilize membranes and increase cell permeability by combining with membrane-associated sterols (Geidam et al., 2007; Ademola et al., 2008; Ademola and Eloff, 2010) and producing changes in cell morphology leading to cytolysis (Geidam et al., 2007). Alkaloids may improve tonicity of the gastrointestinal tract and thus expel the worms or may have a direct effect on the nervous system of the nematodes (Ademola et al., 2008; Lateef et al., 2003). Albendazole works by interference with polymerization of microtubule, where the drug binds to the protein tubulin of the parasite leading to death by starvation (Kareru et al., 2012; Lalchhandama, 2009). The other phytochemicals in the two plants like flavonoids and oleanane type triterpenes may have had their independent or synergistic anthelmintic effects (Zafar et al., 2009).

\subsection{Results of live body weights of the experimental sheep}

Changes in the live body weights of the sheep are recorded in Table 2. There were no significant changes $(\mathrm{P}>0.05)$ in the LBWs of the sheep treated with the herbal extract mixture and Albendazole on day 19 PT compared with day 0 . All the groups had an increase in their mean LBWs by day 19 PT except the untreated group. However, none of the increase was significant $(\mathrm{P}>0.05)$.

Table 2: Effect of herbal extract mixture (E. Leptostachya: $P$. juliflora) on mean $( \pm$ S.D., $n=4)$ live body weights of sheep

\begin{tabular}{|c|c|c|c|c|c|}
\hline & \multicolumn{5}{|c|}{ LIVE BODY WEIGHTS (KG) } \\
\hline DAY PT & UNTREATED & $\begin{array}{c}\text { ALBENDAZOLE } \\
(10 \mathrm{mg} / \mathrm{kg})\end{array}$ & $500 \mathrm{mg} / \mathrm{kg}$ & $1500 \mathrm{mg} / \mathrm{kg}$ & $4500 \mathrm{mg} / \mathrm{kg}$ \\
\hline 0 & $\begin{array}{l}19.4 \pm 4.2 \\
(0 \%)\end{array}$ & $\begin{array}{l}21.0 \pm 3.7 \\
(0 \%)\end{array}$ & $\begin{array}{l}19.6 \pm 5.1 \\
(0 \%)\end{array}$ & $\begin{array}{l}22.3 \pm 4.4 \\
(0 \%)\end{array}$ & $\begin{array}{l}21.0 \pm 5.5 \\
(0 \%)\end{array}$ \\
\hline 3 & $\begin{array}{l}18.5 \pm 3.2^{\mathrm{a}} \\
(-4.6 \%)\end{array}$ & $\begin{array}{l}20.3 \pm 4.4^{b} \\
(-3.3 \%)\end{array}$ & $\begin{array}{l}19.6 \pm 5.4 \\
(0 \%)\end{array}$ & $\begin{array}{l}21.0 \pm 3.0^{\mathrm{d}} \\
(-5.8 \%)\end{array}$ & $\begin{array}{l}21.0 \pm 6.5 \\
(0 \%)\end{array}$ \\
\hline 7 & $\begin{array}{l}18.5 \pm 3.5^{\mathrm{a}} \\
(-4.6 \%)\end{array}$ & $\begin{array}{l}22.2 \pm 2.3 \\
(5.7 \%)\end{array}$ & $\begin{array}{l}19.6 \pm 5.2 \\
(0 \%)\end{array}$ & $\begin{array}{l}20.6 \pm 3.0^{\mathrm{d}} \\
(-7.6 \%)\end{array}$ & $\begin{array}{l}19.6 \pm 6.3^{\mathrm{e}} \\
(-6.7 \%)\end{array}$ \\
\hline 11 & $\begin{array}{l}18.4 \pm 3.2^{\mathrm{a}} \\
(-5.2 \%)\end{array}$ & $\begin{array}{l}20.8 \pm 2.4 \\
(-1 \%)\end{array}$ & $\begin{array}{l}19.0 \pm 4.7^{\mathrm{c}} \\
(-3.1 \%)\end{array}$ & $\begin{array}{l}20.6 \pm 4.1^{\mathrm{d}} \\
(-7.6 \%)\end{array}$ & $\begin{array}{l}20.4 \pm 6.4^{\mathrm{e}} \\
(-2.6 \%)\end{array}$ \\
\hline 15 & $\begin{array}{l}18.9 \pm 3.6 \\
(-2.6 \%)\end{array}$ & $\begin{array}{l}21.7 \pm 2.5 \\
(3.3 \%)\end{array}$ & $\begin{array}{l}20.1 \pm 4.5 \\
(2.6 \%)\end{array}$ & $\begin{array}{l}21.0 \pm 4.2^{\mathrm{d}} \\
(-5.8 \%)\end{array}$ & $\begin{array}{l}21.4 \pm 6.1 \\
(1.9 \%)\end{array}$ \\
\hline 19 & $\begin{array}{l}19.0 \pm 2.5 \\
(-2.1 \%)\end{array}$ & $\begin{array}{l}25.0 \pm 2.6 \\
(19.0 \%)\end{array}$ & $\begin{array}{l}20.5 \pm 4.6 \\
(4.6 \%)\end{array}$ & $\begin{array}{l}22.8 \pm 3.4 \\
(2.2 \%)\end{array}$ & $\begin{array}{c}24.5 \pm 6.2 \\
(16.7 \%)\end{array}$ \\
\hline
\end{tabular}

PT=Post treatment; Mean LBWs with same lettered superscripts are significantly different $(\mathrm{P}<0.05)$ from day 0 LBW in the same column; Untreated=Naturally infected but untreated control group; Negative percentage values (in parentheses) indicate percentage mean LBW decrease from value on day 0 PT 
Nematodes have been reported to cause severe damages to the gastrointestinal tract (GIT) and the host therefore, expends energy and protein repairing these damages caused by these parasites other than for growth (Agaie and Onyeyili, 2007). This could have been responsible for the insignificant changes $(\mathrm{P}>0.05)$ in LBWs of the sheep despite anthelmintic treatment.

Presence of tannins in the leaf and root aqueous extracts of $P$. juliflora and E. leptostachya respectively is reported (Kareru et al., 2012; Wamburu et al., 2013). Because of their reactivity with plant proteins as they are being chewed by ruminant animals, condensed tannins partially protect animals against rumen degradation of proteins, and so increase the flow of amino acids to the small intestines hence, increasing their absorption (FAO, 2011; Min and Hart, 2003; Zafar et al., 2002). This increase may help to counteract the losses of protein attributed to gastrointestinal nematode infection and for immune response to nematode parasites (Barry et al., 2001; Niezen et al., 2002; Zafar et al., 2002; Min and Hart, 2003).

The herbal extract mixture treated groups could have benefitted from better utilization of proteins in the presence of tannins or the weight gains could have been as a result of improved feeding or both or due to better nutrient utilization due to lower worm load. Weight gains in the Albendazole-treated group could have been due to maximization of nutrient utilization as a result of lower worm load. However, determination of total worm count will be essential in future work with this extract mixture to validate weight gains as a result of lower worm loads as EPG counts cannot reliably be used to make conclusions on worm loads.

\subsection{Results of packed cell volumes (PCV) of the experimental sheep}

From Table 3, there were no significant changes $(\mathrm{P}>0.05)$ in the packed cell volumes (PCVs) by day 19 PT compared to day 0 PT except for the extract mixture dose of $1500 \mathrm{mg} / \mathrm{kg} \mathrm{b}$.w. whose PCV significantly dropped $(\mathrm{P}<0.05)$. All the animals recorded pre- and post-treatment PCV values that were within the permissible range of between 24-45\% (Research Animal Resources, University of Minnesota, 2013; Worku et al., 2009) for experimental sheep.

Table 3: Effect of the herbal extract mixture on the mean \pm S.D. $(n=4)$ PCV of the sheep

\begin{tabular}{|c|c|c|c|c|c|}
\hline \multirow[b]{2}{*}{ DAYS PT } & \multicolumn{5}{|c|}{$\% \mathrm{PCV}$} \\
\hline & UNTREATED & $\begin{array}{c}\text { ALBENDAZOLE } \\
(10 \mathrm{mg} / \mathrm{kg})\end{array}$ & $500 \mathrm{mg} / \mathrm{kg}$ & $1500 \mathrm{mg} / \mathrm{kg} *$ & $4500 \mathrm{mg} / \mathrm{kg}$ \\
\hline 0 & $28.71 \pm 2.61$ & $25.97 \pm 4.52$ & $30.29 \pm 2.55$ & $25.17 \pm 2.09$ & $26.33 \pm 2.30$ \\
\hline 19 & $\begin{array}{l}31.74 \pm 4.34 \\
(10.55 \%)\end{array}$ & $\begin{array}{l}30.60 \pm 3.39 \\
(17.83 \%)\end{array}$ & $\begin{array}{l}30.63 \pm 3.95 \\
(1.12 \%)\end{array}$ & $\begin{array}{l}24.21 \pm 3.67 \\
(-3.81 \%)\end{array}$ & $\begin{array}{l}25.51 \pm 3.00 \\
(-3.11 \%)\end{array}$ \\
\hline
\end{tabular}

*Significant difference $(\mathrm{P}<0.05)$ between day 0 and day19; Negative percentage values (in parentheses) indicate percentage decrease in PCV from value on day $0 \mathrm{PT}$

All the groups recorded improved PCV values (thus, reduced degree of anaemia) except the doses at $1500 \mathrm{mg} / \mathrm{kg}$ b.w. and $4500 \mathrm{mg} / \mathrm{kg} \mathrm{b.w.} \mathrm{Anaemia,} \mathrm{following} \mathrm{administration} \mathrm{of} \mathrm{an} \mathrm{agent,} \mathrm{could} \mathrm{be} \mathrm{as} \mathrm{a} \mathrm{result}$ of lysis of blood cells and/or inhibition of blood cell synthesis by the active constituents of the extract (Orisakwe et al., 2003). The higher doses of the extract mixture (1500 and 4500mg/kg b.w.) could have had this effect on the experimental animals thus, recording decreased PCV values. Besides the negative effects worms have on increasing anaemia, the lower percentage increase on mean PCV of the treated animals at $500 \mathrm{mg} / \mathrm{kg}$ b.w. compared to the controls and percentage PCV drops at $1500 \mathrm{mg} / \mathrm{kg}$ b.w. and $4500 \mathrm{mg} / \mathrm{kg} \mathrm{b.w}$. groups may be indicators of the drug effect on the PCV values of sheep. This may also suggest that the two doses whose PCVs dropped may have had a negative stimulatory effect on the hemopoietic system or the animals may have increased water intake (Githiori, 2008). As no abnormal adverse effects were observed during this study after administration of the herbal drug, water intake may not have contributed to this effect as 
no abnormal water intake was observed in all the groups under the same experimental conditions. Each worm is responsible for a daily loss of blood of about $0.05 \mathrm{ml}$ through ingestion and seepage from lesions (Eguale et al., 2007). PCV values are directly related to anaemia, correlated with high FEC and parasite burdens (Dawo and Tibbo, 2005; Worku et al., 2009).

The drop in PCVs in the animals treated with the herbal extract at $1500 \mathrm{mg} / \mathrm{kg} \mathrm{b.w.} \mathrm{and} 4500 \mathrm{mg} / \mathrm{kg}$ b.w. correlated with the lower anthelmintic activities (FECR) of the two groups. On the other hand, the improved PCV values meant that there was reduction of blood loss from the animals due to parasite inhibition or clearance, which can signify recovery from helminthosis and improvement in health status (Agaie and Onyeyili, 2007) as observed with the extract mixture dose of $500 \mathrm{mg} / \mathrm{kg}$ b.w. Negative stimulatory effects were enhanced in the herbal extract mixture groups compared to the control groups with notable increase in anaemia in $1500 \mathrm{mg} / \mathrm{kg} \mathrm{b.w}$. and $4500 \mathrm{mg} / \mathrm{kg}$ b.w. groups. Notable contradiction is the PCV increment in the untreated group despite the fact that the egg count over the period indicated a general increase. However, a higher egg count may not necessarily indicate the level of worm infection (Tarpoff, 2010).

Other similar in vivo work has been reported. A maximum EPG reduction of $50.3 \%$ on Arsi Bale goats was achieved by Dawo and Tibbo (2005) using crude powder of Halothamnus somalensis. Aqueous extract of Daniellia oliveri reduced feacal egg count in naturally infected sheep by $12.8 \%$ by day 14 PT at a dose of $1200 \mathrm{mg} / \mathrm{kg}$ b.w. (Adama et al., 2012). Crude powder and crude methanolic extract of Ferula costata showed significantly higher reduction in EPG compared to untreated control at all stages PT with a maxima on day $14(47.9 \%)$ for $3 \mathrm{~g} / \mathrm{kg}$ b.w. but which was significantly lower than the positive control (Levamisole) at $7.5 \mathrm{mg} / \mathrm{kg}$ b.w. (99.39\%) (Kakar et al., 2013). The average PCV values were not significantly different for goats treated with aqueous leaf extract of $C$. pyramidalis compared to Doromectintreated groups and the untreated groups. The LBWs of the animals treated with the extract did not change significantly except those treated at the highest dose of $5 \mathrm{mg} / \mathrm{kg} \mathrm{b.w}$. (Robson et al., 2012). In evaluation of in vivo anthelmintic activity using Boer goats, Worku et al. (2009) observed that groups treated with wormwood and tobacco with added copper sulphate resulted in dramatic decreases in PCV values and related this to toxic effects of these plant extracts.

\section{Acknowledgements}

The authors thank Research, Production and Extension Division of Jomo Kenyatta University of Agriculture and Technology for funding this project. Mr. Kimanthi (Animal house caretaker), for dedicated care of the experimental animals and a helping hand during faecal sampling of the animals.

\section{References}

[1]. Adama, K., Amadou, T., Man, N., Hamidou, T.H. and Gaston, B.A.M. (2012). Anthelmintic activity of Daniellia oliveri (Rolfe) Hucht. and Dalz (Caesalpiniaceae) in sheep in Burkina Faso, Journal of Research in Antimicrobials: 1(1): 049-055.

[2]. Ademola, I.O., Ajayi, A., and Okotie, S.V. (2008). Larvicidal effects of Aframomum danieli seed extracts against gastrointestinal nematode of sheep: in vitro studies, African Ethnomedicines Network: 5(3): 173-179.

[3]. Ademola, I.O. and Eloff, J.N. (2010). In vitro anthelmintic activity of Combretum molle (R. Br. ex G. Don) (Combretaceae) against Haemonchus contortus ova and larvae, Veterinary Parasitology: 169(1-2): 198-203.

[4]. Agaie, B.M. and Onyeyili, P.A. (2007). Anthelmintic activity of the crude aqueous leaf extracts of Anogeissusleio carpus in sheep, African Journal of Biotechnology: 6: 1511-1515.

[5]. Barry, T. N., McNeill, D. M. and McNabb, W. C. (2001). Plant secondary compounds; their impact on nutritive value and upon animal production, pp. 445-452. Proc. XIX Int. Grass. Conf., Sao Paulo, Brazil.

[6]. Burke, J.M., Wells, A., Casey, P. and Kaplan. (2009). Herbal dewormer fails to control gastrointestinal nematodes in goats, VeterinaryParasitology: $160(1-2): 168-70$.

[7]. Dave, S., Patil, U.K., Bhaiji, A., Baghel, U.S., Yadav, S.K. and Sharma, V.K. (2009). In vitro anthelmintic activity of leaves of Spinacia oleracea Linn., International Journal of Toxicological and Pharmacological Research: 1(1): 21-23.

[8]. Dawo, F. and Tibbo, M. (2005). Anthelmintic effect of Halothamus somalensis in Arsi-Bale goats,Livestock Research for Rural Development: 17.

[9]. Deore, S.L. and Khadabadi, S.S. (2010). In vitro anthelmintic studies of Chlorophytum borivilianum Sant. and Fernandez tubers, Indian Journal of Natural Products and Resources: 1(1): 53-56.

[10]. Ebenshade, H.W. and Grainger, A. (1980). The Bamburi reclamation project, International Tree Crops Journal: 1: $199-202$.

[11]. Eguale, T. and Giday, M. (2009). In vitro anthelmintic activity of three medicinal plants against Haemonchus contortus, International Journal of Green Pharmacy: 3(1): 29-34.

[12]. Food and Agriculture Organization of the United Nations (FAO). Naturally occurring plant tannins as a means of controlling intestinal nematode infections in ruminants, http//:www.fao.org/teca/content/naturally-occurring-plant-tannins-means-controllingintestinal-nematode-infections-ruminants. Accessed on March 11, 2011.

[13]. Geidam, Y.A., Ambali, A.G. and Onyeyili, P.A. (2007). Preliminary phytochemical and antibacterial evaluation of crude aqueous extract of Psidium guajava leaf, Journal of Applied Sciences: 7(4): 511-514.

[14]. Githiori, J.B. (2004). Evaluation of anthelmintic properties of ethnoveterinary plant preparations used as livestock dewormers by pastoralists and smallholder farmers in Kenya, Ph.D. Thesis, Swedish University of Agricultural Sciences, Uppsala, Sweden.

[15]. Hansen, J. and Perry, B. (1994). The epidemiology, diagnosis and control of helminthes parasites of ruminants, pp. 62-63. International Laboratory for research on Animal Diseases (ILRAD), Nairobi, Kenya. 
[16]. Kareru, P.G. (2008). Ethnomedicine practices, analysis and standardization of a herbal anthelmintic drug used by the Embu and Mbeere peoples of Kenya, PhD thesis, Jomo Kenyatta University of Agriculture and Technology, Juja, Kenya.

[17]. Kareru, P.G., Ombasa, O., Rukunga, G., Mbaria, J., Keriko, J.M., Njonge, F.K. and Owuor, B.O. (2012). In vitro anthelmintic effects of two Kenyan plant extracts against Haemonchus contortus adult worms, International Journal of Pharmacological Research: 2(3): 113-115.

[18]. Kakar, S.A., Tareen, R.B., Sandhu, Z.U., Azam, M.K., Saeed, U.K., Zafar, I. and Jabeen, H. (2013). In vitro and in vivo anthelmintic activity of Ferula costata (Kor.) against gastrointestinal nematodes of sheep, Pak. J. Bot.: 45(SI): $263-268$.

[19]. Lalchhandama, K. (2009). Cestocidal activity of Acacia caesia stem bark on Raillietina echinobothrida, Pharmacognosy Research: 1(4): 179-184.

[20]. Lateef, M., Iqbal, M., Rauf, U. and Jabbar, A. (2006). Anthelmintic activity of Carum capticum seeds against gastro-intestinal nematodes of sheep, J. Anim. Pl. Sci.: 16: 35-36.

[21]. Lateef, M., Zafar, I., Khan, M.N., Akhtar, M.S. and Jabbar, A. (2003). Anthelmintic activity of Adhatoda vesica roots, International Journal of Agriculture and Biology: 5(1): 86-89.

[22]. Maghembe, J.A., Kariuki, E.M. and Haller, R.D. (1983). Biomass and nutrient accumulation in young Prosopis juliflora at Mombasa, Kenya, Agroforestry Systems: 1: 313-321.

[23]. Min, B.R. and Hart, S.P. (2003). Tannins for suppression of internal parasites, Journal of Animal Science: 81(E. Suppl. 2): E102E109.

[24]. Niezen, J.H., Charleston, W.A.G., Robertson, H.A., Shelton D., Waghorn, G.C. and Green, R. (2002). The effect of feeding sulla (Hedysarum coronarium) or lucerne (Medicago sativa) on lamb parasite burdens and immunity to gastrointestinal nematodes, Veterinary Parasitology: 105: 229-245.

[25]. Orisakwe, O.E., Afonne, O.J., Chude, M.A., Obi, E. and Dioka, C.E. (2003). Sub-chronic toxicity studies of the aqueous extract of Boerhavia diffusa leaves, Journal of Health Science: 49(6): 444-447.

[26]. Research Animal Resources, University of Minnesota. Reference values for laboratory animals, www.ahc.umn.edu/rar/refvalues.html. Accessed on July 13, 2013.

[27]. Robson, R.B., López, J.A., Santos, L.C., Zacharias, F., David, J.M., David, J.P. and Lima, F.W.M. (2012). Biological effect of leaf aqueous extract of Caesalpinia pyramidalis in goats infected with gastrointestinal nematodes, Evidence-Based Complementary and Alternative medicine: 2012(2012): http://dx.doi.org/10.1155/2012/510391.

[28]. Sujon, M.A., Mostofa, M., Jahan, M.S., Das, A.R. and Rob, S. (2008). Studies on medicinal plants against gastrointestinal nematodes of goats, Bangladesh Journal of Veterinary Medicine:6 (2): 179-183.

[29]. Tarpoff, A.J. (2010). Comparative efficacy of two ivermectin pour-on anthelmintics in beef steers in a commercial feed yard, MSc. Thesis, Kansas State University, Manhattan, Kansas, United States of America.

[30]. Wamburu, R.W., Kareru, P.G., Mbaria, J.M., Njonge F.K., Nyaga, G. and Rechab, S.O. (2013). Acute and sub-acute toxicological evaluation of ethanolic leaves extract of Prosopis juliflora (Fabaceae), Journal of Natural Sciences Research: 3(1): 8-11.

[31]. Wood, I. B., Amaral, N. K., Bairden, K., Duncan, J. L., Kassai, T., Malone, J. B., Jr., Pankavich, J. A., Reinecke, R. K., Slocombe, O. and Taylor, S. M. (1995). World Association for the Advancement of Veterinary Parasitology (W.A.A.V.P.) second edition of guidelines for evaluating the efficacy of anthelmintics in ruminants (bovine, ovine, caprine), Veterinary Parasitology: 58: 181-213.

[32]. Worku, M., Franco, R. and Miller, J.H. (2009). Evaluation of the activity of plant extracts in Boer goats, American Journal of Animal and Veterinary Sciences: 4(4): 72-79.

[33]. Zafar, I., Bachaya, H.A., Nisar, M.K., Jabbar, A., Gilani, A.H., and Islam, U.D. (2009). In vitro and in vivo anthelmintic activity of Terminalia arjuna bark, International Journal of Agriculture and Biology: 11(3): 273-278.

[34]. Zafar, I., Mufti, K.A. and Nisar, M.K. (2002). Anthelmintic effects of condensed tannins, International Journal of Agriculture and Biology: 4(3): 438-440. 